Hispania, 2019, vol. LXXIX, n. ${ }^{\circ}$ 263, septiembre-diciembre, págs. 757-784 ISSN: 0018-2141, e-ISSN: 1988-8368, https://doi.org/10.3989/hispania.2019.019

\title{
«Ahí van esos chulos». Militares, indisciplina y orden público en la pri- mavera española de 1936*
}

\author{
Manuel Álvarez Tardío ${ }^{1}$ \\ Universidad Rey Juan Carlos \\ manuel.tardio@urjc.es
}

RESUMEN: Este artículo se ocupa de uno de los aspectos ineludibles en un análisis político de los últimos meses de la Segunda República española: el papel de los militares. El objetivo fundamental es profundizar en una perspectiva de proximidad que enriquezca lo que ya sabemos sobre la preparación del golpe y sus protagonistas. La cuestión de los militares y el gobierno del Frente Popular se ha venido abordando desde el punto de vista de las tramas conspirativas, lo que podría definirse como una visión desde arriba del golpe. El artículo muestra, mediante un estudio de caso, la importancia de complementar esa visión con un enfoque desde abajo. Con ese objetivo, se han utilizado fuentes judiciales y locales que aportan una información muy significativa sobre el papel de algunos oficiales durante aquella primavera y el impacto de la violencia politica y la quiebra de las jerarquías sociales tradicionales sobre la disciplina militar.

Palabras ClaVe: España; Segunda República; militares; violencia; política.

\footnotetext{
* Este artículo se inscribe en el proyecto de investigación nacional con referencia HAR2015-65115-P (MINECO/FEDER).

Archivos citados: Archivo General de la Administración, Alcalá de Henares (AGA); Centro Documental de la Memoria Histórica, Salamanca (CDMH); Archivo Privado de José Sanjurjo, Madrid (AJS); Archivo de la Fundación José María Castañé, Madrid (AFJMC); Archivo Secreto Vaticano, Roma (ASV); Archivo Histórico Municipal de Alcalá de Henares (AHMAH); y National Archives, Richmond, Londres (NA).

${ }^{1}$ ORCID iD: https://orcid.org/0000-0002-2712-2687.
}

Copyright: (C) 2019 CSIC. Este es un artículo de acceso abierto distribuido bajo los términos de una licencia de uso y distribución Creative Commons Reconocimiento 4.0 Internacional (CC-BY 4.0) 
"There go those cocky types". The Army, indiscipline and public order in the Spanish Spring of 1936

ABSTRACT: This article deals with one of the most decisive aspects in the political analysis of the final months of the Second Spanish Republic: the role of the Army. Its main objective is more close-up and deeper analysis of what we know about the preparation of the coup d'état and its protagonists. The question regarding the military and the Popular Front Government has so far been addressed from the point of view of conspiracy plots, which could be defined as a top-down view of the coup. This article takes a case study to show the importance of balancing that vision with a bottom-up approach. To that end, judicial and local sources have been used to provide very meaningful information on the role of certain officers during that spring, and the impact of political violence and the breakdown of traditional social hierarchies on military discipline.

KeY wORds: $\quad$ Spain; Second Republic; military; violence; politics.

CÓMO CITAR ESTE ARTÍCULO/CITATION: Álvarez Tardío, Manuel, «"Ahí van esos chulos". Militares, indisciplina y orden público en la primavera española de 1936», Hispania, 79/263 (Madrid, 2019): 757-784. https://doi.org/10.3989/hispania.2019.019.

\section{Más allá de la elite de la conspiración: una perspectiva comple- MENTARIA}

Uno de los protagonistas ineludible en el análisis de los últimos meses de la Segunda República es el Ejército. Primero, porque la cuestión militar había sido central en la agenda de los gobiernos del primer bienio. Segundo, porque el debate sobre la politización del estamento militar fue una constante durante toda la vida de la República, bien fuera para denunciar que era un reducto de reaccionarios al servicio de la Monarquía, bien para advertir, en un sentido totalmente contrario, sobre el peligro de bolchevización y desaparición de la disciplina militar. Y tercero, y más relacionado si cabe con el primer semestre de 1936, porque fue el fracaso parcial de una insurrección protagonizada por algunos militares lo que provocó el comienzo de la guerra ${ }^{2}$.

Dado este último hecho decisivo, la principal perspectiva desde la que se ha abordado la relación entre el Ejército y la política del Frente Popular ha sido la de la organización del golpe. Es comprensible, por tanto, que durante los últimos años se haya puesto el foco de atención sobre la conspiración. Se trataba

2 Sobre la reforma militar en el primer bienio: ALPERT, 1982. JULIÁ, 2008: 276-284. Para la política militar en el segundo bienio: ÁLVAREZ TARDÍO, 2018: 97-104. GIL-ROBLES, 2006: 237-254. HIDALGO, 2015. Perspectiva general sobre ejército y República: CARDONA, 1983. PAYNE, 1986. AGUILAR OLIVENCIA, 1986.

Hispania, 2019, vol. LXXIX, nº 263, septiembre-diciembre, págs. 757-784, ISSN: 0018-2141, e-ISSN: 1988-8368 https://doi.org/10.3989/hispania.2019.019 
de conocer mejor y más a fondo qué militares habían participado y con qué apoyos civiles habían contado, amén de si hubo una o varias tramas y si, finalmente, el golpe fue algo más bien chapucero, carente de apoyos firmes hasta el final y muy determinado por las circunstancias o, por el contrario, estuvo bien organizado y planificado. Ciertamente, la conspiración había sido ya objeto de análisis desde el final mismo de la guerra, empezando por la reconstrucción interesada de las memorias personales de sus protagonistas. Pero, como ha señalado recientemente un especialista, el paso de los años no siempre había servido para superar esos «tópicos y reiteraciones» que caracterizaron a numerosos estudios relacionados con la guerra civil española y su desencadenamiento ${ }^{3}$.

En todo caso, hoy parecen ya bien planteadas las cuestiones fundamentales del debate. No está cerrado ni mucho menos, pero cada vez se estrecha más el círculo de las incógnitas relevantes. La trama de la conspiración y sus protagonistas son relativamente bien conocidas para la historiografía. Por supuesto, por su especial relevancia posterior, la biografía de Franco ha sido estudiada a fondo; pero también se ha publicado recientemente sobre otros jefes militares, empezando por el general Sanjurjo; y la documentación de archivo ha permitido profundizar en la labor golpista de mandos tan relevantes en su momento como Manuel Goded, Emilio Mola, Joaquín Fanjul, Gonzalo Queipo de Llano o José Enrique Varela 4 .

Ahora bien, existe otra dimensión sustantiva en la vida política de los últimos meses de la República, también relacionada con el Ejército, apenas estudiada. Se trata de la relación que mantuvieron las tropas con la población civil y los grupos políticos durante aquella compleja primavera de 1936. Aunque sólo fuera porque, según algunos cálculos, cuatro de cada cinco oficiales se sumaron a la insurrección, merecería la pena conocer mejor qué los llevó a hacerlo y cómo se comportaron en los meses previos, en un contexto en el que el Gobierno estaba tomando decisiones importantes de traslados y control de sus superiores ${ }^{5}$. Una explicación aparentemente satisfactoria es la que atribuye el comportamiento de los oficiales a su ideología antirrepublicana y antirrevolucionaria; los militares, en ese sentido, se habrían radicalizado como resultado

${ }^{3}$ Entrecomillados, en ALÍA MIRANDA, 2011: 15. Además, sobre la conspiración: GARCÍA VENERO, 1967. VIÑAS, 1978. ARÓSTEGUI, 2006. SACANELL, 2008. CARDONA, 2010. PAYNE, 2016. PUELL DE VILA, 2013. Y para los testimonios y el papel de los protagonistas: BERTRAND GÜELL, 1939. GODED, 1938. MAIZ, 1952. LIZARZA, 1986. FRANCO SALGADO-ARAUJO. 1976. SAINZ RODRÍGUEZ, 1978.

${ }^{4}$ MARTÍNEZ RODA, 2012. SACANELL, 2004. BLANCO ESCOLÁ, 2002. FERNÁNDEZ-COPPEL, 2008. RODRÍGUEZ JIMÉNEZ, 2005. TOGORES SÁNCHEZ, 2010. TUSELL, 1993. ALONSO BAQUER, 2005. GARCÍA ÁLVAREZ-COQUE, 2017. REY, 2 (Roma, 2018).

${ }^{5}$ Dato de oficiales, en ALÍA MIRANDA, 2011: 129, que sigue a CARDONA, 2006. 
de la victoria de las izquierdas en las elecciones, que no esperaban ni deseaban. Al fin y al cabo, ahí estaban algunos hechos previos que confirmarían ese sesgo ideológico, como la fracasada sanjurjada de agosto de 1932 o la creación y desarrollo de una organización como la Unión Militar Española (UME), en la que se habrían ido incorporando desde 1935 oficiales dispuestos a entablar relaciones para conspirar contra el régimen ${ }^{6}$.

Sin embargo, por obvia que pueda ser esa explicación o por relevantes que puedan ser las evidencias empíricas que la corroboran, no es menos cierto que del paso que va de la identificación con una ideología concreta a un comportamiento abiertamente golpista puede haber una distancia significativa, que no se salva simplemente por el impacto de la propaganda, salvo en los casos de una militancia creyente y muy comprometida. Tal vez, la apelación a actitudes ideológicas y al reaccionarismo de los oficiales simplifique demasiado la cuestión e impida comprender por qué algunos de ellos, que venían de haberse opuesto a la prolongación del régimen de Primo de Rivera, o incluso que habían respaldado la llegada de la República y habían tenido actitudes pragmáticas durante los años anteriores, concluyeron apoyando el golpe. Un factor relevante es el de la dimensión corporativa, esto es, el hecho de pertenecer a un cuerpo diferenciado que ahora, en tanto que involucrado en la derrota del octubre de 1934, se sentía identificado y amenazado; y todo esto mientras la propaganda conservadora denunciaba también la infiltración marxista en el cuerpo. Pero no lo es menos el que se refiere a la percepción de que un universo consolidado de códigos de comportamiento estaba siendo amenazado. Porque si muchos militares podían identificar con algo concreto la idea de una revolución social inminente, esto era, probablemente, con la quiebra del principio de jerarquía y autoridad tal y como estos habían sido entendidos y practicados desde muy atrás; y que tenía - conviene recordarlo - mucho que ver con cómo veían su rol en la sociedad y la política de orden público de la época ${ }^{7}$. Y para esto, ciertamente, no era necesario una propaganda extensa y extrema que les confirmara en la amenaza de otro octubre revolucionario, sino que había otras señales más próximas que podían palpar en su día a día y que contribuían a acrecentar su inquietud, haciéndolos más vulnerables al alarmismo.

Algunos estudios sobre la preparación militar del golpe han argumentado que los «militares africanistas y de la UME estaban asustados ante la revolución social»; y que puede resultar equivocado pensar que fueron simplemente «un instrumento de las fuerzas políticas conservadoras», pues el efecto de ese miedo hacía que fueran ellos «los primeros interesados» en preparar una acción violenta. Es decir, que habrían sido más autónomos de lo que a veces se ha

\footnotetext{
${ }^{6}$ BUSQUETS, 1986. PAYNE, 2005: 328-329.

7 Sobre militares y orden público: BALLBÉ, 1983. PAYNE, 1986.
} 
pensado, no siendo un simple brazo armado y dócil de los políticos ${ }^{8}$. Sin embargo, cabe preguntarse por qué algunos llegaron a temer esa supuesta «revolución social»; y, sobre todo, si hubo elementos concretos en su experiencia cotidiana que los llevaron a concluir que había un peligro revolucionario, sobre todo entre los oficiales de graduación intermedia que finalmente apoyaron la insurrección. Porque si está claro que los graves problemas políticos y sociales habidos entre marzo y junio de 1936 no fueron el fruto de un asalto bolchevique al poder, planificado y organizado, no lo es menos que aquellos, especialmente la violencia política y la usurpación de funciones de seguridad y vigilancia por grupos parapoliciales, existieron y alcanzaron una dimensión que preocupó no ya a los conservadores, sino a la propia izquierda republicana en el Gobierno9.

Por consiguiente, una cuestión central, pero apenas estudiada, es la que nos permita entender qué aspectos concretos influyeron en el ánimo de los oficiales y soldados que se pronunciaron en julio pero que no formaban parte del núcleo central de la trama conspirativa. No es tanto si pensaban que había una «revolución social» en marcha, sino, qué los llevó a aceptar esa premisa y cómo influyeron algunos sucesos locales.

No es mucho lo que sabemos sobre este campo, aunque sí tenemos algunas pistas que sugieren que, además de conspirar porque creyesen que el Frente Popular estaba dejando el campo libre a la revolución, algunos oficiales vivieron de cerca el problema de la confrontación directa con los simpatizantes y afiliados de los partidos de Frente Popular, especialmente cuando los jóvenes radicalizados de estos últimos se dedicaron a realizar labores ilegales de vigilancia y cacheos en la vía pública. Al fin y al cabo, el ejército había tenido un papel decisivo en la derrota de la revolución de octubre de 1934 en Asturias y Cataluña, y eso los había convertido en una de las dianas predilectas en las que las izquierdas identificaban el llamado «bienio negro». Nos faltan estudios, pero algunos datos apuntan a que el odio hacia los militares fue más allá de la

8 ALÍA MIRANDA, 2011: 115.

9 Es significativo el testimonio de Martínez Barrio referido a las semanas que ocupó interinamente la Presidencia de la República: habló de la acción de «los núcleos extremistas de izquierdas» como «el drama de cada día, y a veces de cada hora», MARTÍNEZ BARRIO, 1983: 329. Por otra parte, la orden cursada por el ministro de la Gobernación a todos los gobernadores el 9 de abril, reconocía abiertamente el problema de los cacheos ilegales en la vía pública, realizados por individuos armados que actuaban a modo de agentes. En AGA, caja 2416, legajo 1015. Citado en MACARRO, 2000: 441. Igual de significativa es la circular del gobernador de Ciudad Real a los ayuntamientos de la provincia advirtiendo sobre la proliferación de ilegalidades, citado en REY, 2008: 495. Para el análisis del orden público y la violencia durante esa primavera, así como los diferentes enfoques sobre el peso de la radicalización de las izquierdas obreras y su responsabilidad en el aumento de la violencia política, véanse los estudios o ensayos de CIBRIÁN, 6 (Madrid, 1978). CRUZ, 2006. RANZATO, 2011. GONZÁLEZ CALLEJA, 2015. LEDESMA, 2013. PAYNE, 2016. 
propaganda electoral y se plasmó en comportamientos concretos durante la primavera. En Santa Cruz de Tenerife, por ejemplo, no sólo fue la llegada del general Franco lo que exacerbó los ánimos; la agitada campaña de las izquierdas después de las elecciones se extendió a otros objetivos. En un mitin celebrado en La Orotava, el recién elegido diputado comunista por Santa Cruz de Tenerife, Florencio Sosa Acevedo, instó a acciones violentas contra los oficiales $^{10}$.

Que no se trató sólo de retóricas de mítines y periódicos de partido lo muestran algunos indicios. Sin duda, este es un aspecto muy poco investigado si se compara con lo que conocemos del grueso de la violencia política o del anticlericalismo durante la primavera, pero disponemos de datos que indican que los insultos y ataques físicos contra oficiales del ejército no fueron excepcionales. En Melilla, por ejemplo, al acabar la jornada de trabajo, y todavía más los días festivos, era habitual que «los obreros y los jóvenes» de izquierdas, cuando se encontraban con un oficial lo «insultaban». Y es que entre las izquierdas locales se consideraba que crecía el número de oficiales simpatizantes del fascismo, como explicaba el delegado del Gobierno en un informe a su ministro. «Más de una vez», recordaba el soldado José Llordés, «habíamos presenciado algún día de fiesta por la tarde estos insultos en plena calle y en los mismos cafés que tenían las mesas en la acera donde se sentaba los oficiales. Al pasar una recua de mozalbetes con chicas de su edad con pañuelos rojos anudados al cuello (...) y el puño en alto frente a las mesas de los oficiales, les maltrataban y escupían $\rangle^{11}$.

También hay indicios de ese tipo de conflictos en los partes de novedades elaborados por los mandos de cada una de las divisiones militares del país. Se trata de una información muy valiosa por su carácter de reservada e interna. Así, el comandante militar de Toledo, coronel Moscardó, llamó la atención sobre el hecho de «que sus cadetes eran vilipendiados en las calles de Toledo, sobre todo por los vendedores de prensa obrera», asegurando además que les había dado permiso para defenderse usando sus armas ${ }^{12}$. Y por esa misma

10 Carta de Francisco Franco al ministro de la Guerra, Santa Cruz de Tenerife, 22-51936; y La Prensa, 21-5-1936, en AFJMC, legajo 7494. Al parecer, Sosa Acevedo habría instado al «degüello de oficiales». En el ambiente caldeado de Tenerife, al que se ha aludido más arriba, un teniente de infantería fue agredido con un arma de fuego, resultando heridos tanto él como «su acompañante y un transeúnte», todo esto ya bien entrado el mes de julio y poco antes del golpe. BLÁZQUEZ MIGUEL, 2009: 633. RIVAS GARCÍA, 2018.

${ }_{11}$ José Llordés Badía, Al dejar el fusil, 1968, citado en PAYNE, 2016: 277. Informe del delegado del gobierno al ministro de la Gobernación, en CRUZ, 2006: 209.

${ }_{12}$ El entrecomillado es parte del resumen que hace BAHAMONDE, 41/1 (Madrid, 2011): 71. Como indicativo de esos choques con militares en Toledo contamos con alguna información ilustrativa, aunque poco precisa. En el mes de junio, un grupo de izquierdistas, que realizaba cacheos en la calle, se topó con un teniente del Ejército que les respondió sacando el arma e hiriendo a uno de ellos. BLÁZQUEZ MIGUEL, 2009: 648. También CRUZ, 2006: 208, menciona una «reyerta entre cadetes de la Academia de Toledo y grupos de paisanos», aunque no 
fuente, los partes de novedades, conocemos algunos detalles importantes sobre la situación en Madrid. A primeros de marzo uno de esos cruces de insultos o burlas terminó mal, con un enfrentamiento entre un grupo de individuos y un oficial en la calle Caballero de Gracia. De acuerdo con la versión recogida en el parte, los primeros habrían insultado al segundo llamándole «cochino de Asturias $\rangle^{13}$. Si hacemos caso al testimonio de capitán de Infantería Virgilio Álvarez Buznego, expedientado por propagar entre sus compañeros un listado de demandas a raíz de esos sucesos, la «oficialidad» había estado experimentando «malos tratos» en las calles de la capital durante esas semanas. Probablemente muchos se quedaron en insultos o miradas amenazantes, sin llegar al extremo del anterior. Pero merecería la pena saber más sobre cómo se produjeron y cuál era el perfil político y social de quienes los protagonizaron ${ }^{14}$.

Sabemos, por ejemplo, que algunos enfrentamientos verbales entre grupos de izquierdistas y oficiales derivaron en choques violentos, bien porque los primeros planificaron algún tipo de agresión o bien porque los segundos respondieron a alguna provocación o disputa verbal previa. No obstante, los datos que tenemos de estos episodios son fragmentarios e insuficientes para sacar conclusiones. Así, un «militar retirado» fue agredido en Morón de la Frontera en marzo. Parece también que en El Ferrol hubo varios enfrentamientos entre los militares allí destinados y grupos de izquierdistas locales. Sabemos que durante la grave jornada de violencia vivida en Granada el 10 de marzo se produjo el hecho «inquietante» - en palabras del entonces presidente de la República, Alcalá-Zamora - de «haber sido hostilizada la fuerza del Ejército». Por esas mismas fechas, en una calle de la capital un comandante del Ejército se vio rodeado por un grupo de personas que intentaban liberar a otra que él había detenido. En Guadalajara, durante la celebración del desfile con motivo del aniversario de la proclamación de la República, el 14 de abril, un oficial de Artillería y un derechista resultaron heridos, tras lo cual se produjeron desórdenes y grupos de izquierdistas apedrearon el casino y algunos negocios de la localidad. Y en Jaca, una ciudad donde tenía su sede un regimiento, un militar respondió a unos insultos previos y a punto estuvo de desencadenarse un conflicto más grave si no llega a ser por la intervención de las autoridades civiles y militares ${ }^{15}$. En todo caso, desconocemos los detalles de las circunstancias en que se produjeron todos esos episodios, por lo que apenas pueden servirnos

aporta la fecha concreta; eso sí, asegura que, si bien el gobernador civil apoyó a los civiles implicados, el 30 de junio se «celebró el desfile de los cadetes por la plaza de Zocodover entre los aplausos del público».

13 BAHAMONDE, 41/1 (Madrid, 2011): 72.

${ }_{14}$ Capitán, en BAHAMONDE, 41/1 (Madrid, 2011): 73.

15 Morón, Guadalajara y Jaca, en BLÁZQUEZ MIGUEL, 2009: 625, 651 y 655. Otros, en CRUZ, 2006: 208. Granada, en ÁLVAREZ TARDÍO y VILLA GARCÍA, 2010: 261-264. ALCALÁ-ZAMORA, 2011: 278. 
para apuntar que, efectivamente, hubo una tensión significativa en algunas localidades, similar a la que refería el soldado Llordés para Melilla, y que en ocasiones se pasó de los cruces de insultos a las manos e incluso a las armas.

Uno de los sucesos más graves que conocemos se produjo en Logroño el 14 de marzo. En este caso, a diferencia de los anteriores, sí tenemos alguna información relevante sobre el contexto. Alcalá-Zamora se refirió en su dietario a los «graves sucesos» ocurridos en esa ciudad ${ }^{16}$. Por su parte, Alfredo Muñiz, el redactor jefe del diario madrileño El Heraldo, recogió en su dietario algunos detalles sobre lo sucedido. Aquí no se trató de un simple intercambio de improperios que terminó en riña o agresión, sino que el enfrentamiento con los oficiales formó parte de un conflicto partidista e ideológico previo. Primero, se produjeron detenciones de fascistas en la sede local de Falange, acusados de tener armas. Al día siguiente, frente al juzgado donde estaban los detenidos, un grupo de izquierdistas «incendiaron un automóvil» que asociaban con un compañero de los primeros y donde dijeron haber encontrado un arma. Y al rato, estos mismos asaltaron la sede de Falange, «arrojaron los muebles por las ventanas» $\mathrm{y}$ «los prendieron fuego», todo mientras simpatizantes de izquierdas formaban un cordón de supuestos curiosos que servía para impedir el paso de la policía y los bomberos. Viendo la impotencia policial, estos mismos asaltantes hicieron más de lo mismo, incendio incluido, en las sedes de Acción Riojana, que era el grupo cedista local, y el Círculo Carlista. Los guardias de Asalto sólo consiguieron pararlos cuando trataban de continuar los asaltos en el Círculo Agrario, con el trágico resultado de un asaltante muerto.

Horas más tarde, después de que manifestantes izquierdistas protestaran ante el Gobierno Civil porque la policía había usado armas para disolverlos, «uno de los grupos, en la calle de la República, tropezó con un Oficial de Artillería» al que, muy probablemente, conocían de antemano y acusaban de tener «ideas fascistas». Le insultaron y este «echó mano a la pistola», siendo además «auxiliado por dos compañeros». Estos lograron escapar y «buscar refugio en el Ayuntamiento», frente al que se formó una nueva concentración de manifestantes izquierdistas. Al rato, el alcalde y las autoridades militares de la ciudad, que acudieron a la llamada del primero, intentaron trasladar a los oficiales perseguidos, al parecer custodiados por algunos simpatizantes de izquierdas para evitar que los agredieran. Pero la situación no terminó ahí. Al poco, hubo un enfrentamiento entre los grupos de exaltados y los soldados que hacían guardia en el cuartel. No conocemos bien las circunstancias, aunque parece que antes los primeros habían encendido una hoguera y se habían cruzado «insultos y empujones». En todo caso, según la investigación militar posterior, se hicieron disparos desde el grupo de paisanos concentrados frente al cuartel,

\footnotetext{
${ }^{16}$ ALCALÁ-ZAMORA, 2011: 296.
}

Hispania, 2019, vol. LXXIX, nº 263, septiembre-diciembre, págs. 757-784, ISSN: 0018-2141, e-ISSN: 1988-8368 https://doi.org/10.3989/hispania.2019.019 
a lo que los soldados respondieron también con fuego y provocaron al menos ocho víctimas, de las cuales tres murieron. Por si lo ocurrido hasta ese momento no fuera suficiente, minutos después grupos de izquierdistas «incendiaron el Diario de la Rioja, periódico de la derecha, que quedó totalmente destruido» e hicieron lo mismo con cuatro conventos de la localidad, dos escuelas regentadas por religiosos y cinco iglesias ${ }^{17}$.

Si estos hechos de Logroño tuvieron una repercusión notable, en tanto que se vieron involucrados directamente tanto el comandante militar de la plaza como el coronel en jefe del Regimiento, incluso es muy probable que influyeran en el cese del recién estrenado gobernador civil de la provincia ${ }^{18}$, la información de los partes internos indica que no fue el único suceso que contribuyó a excitar los ánimos del estamento militar. No en vano, parece que el citado choque en la madrileña calle Caballero de Gracia «causó profunda irritación en los cuarteles» de la capital - e incluso que estuvo relacionado con el incendio de la iglesia de San Luis_-, según ha señalado el historiador Ángel Bahamonde, que ha analizado esos partes militares de la primavera. Aunque el Gobierno negó el día 17 de marzo, por boca del ministro de la Guerra, cualquier problema en los cuarteles, resulta significativo que tres días antes el presidente de la República diera cuenta en su diario de la existencia de una reunión «atrevida e irregular» de «elementos militares», deseosos de «protestar de los escándalos y ultrajes» $\rangle^{19}$.

Además, por lo que se refiere a la provincia de Madrid, el de la calle Caballero de Gracia no fue el único choque entre civiles y oficiales que pasó de un intercambio más o menos tenso de amenazas o insultos. Ya más avanzada la

${ }_{17}$ Para este párrafo y el anterior sigo, en parte, el relato de MUÑIZ, 2009: 81, de donde proceden casi todos los entrecomillados, complementado con información del Ministerio de Gobernación, en CDMH, PS Madrid, legajos 1536 y 152. Y ASV, Nunz. C. 945, F. 3. Además, detalles procedentes del informe del gobernador civil de la provincia, publicado pocas horas después del suceso, en La Rioja (Logroño), 15-3-1936, citado en FANDIÑO PÉREZ, 2 (Madrid, 2001). El informe del gobernador es el que habla de que los oficiales trasladados desde el ayuntamiento iban "protegidos por elementos del Frente Popular». BLÁZQUEZ MIGUEL, 2009: 642, basándose en prensa local, sí afirma que estos intentaron asaltar el cuartel, lo que no aparece en el relato de Muñiz. Además, añade que «en estos sangrientos combates callejeros cae herido gravísimamente un comandante, siendo la inmediata contrapartida el asesinato por falangistas de dos comunistas». El entrecomillado «insultos y empujones», en GIL ANDRÉS, 2000: 251, de quien procede el dato de la investigación militar posterior. Según este autor, los asaltos a las sedes derechistas se habrían producido después del intercambio de disparos con los soldados y «como protesta por lo sucedido».

${ }_{18}$ Significativamente, el cesado, Carlos Martínez Shaw, había llegado el día 24 de febrero asegurando que la conservación del orden público era una de sus prioridades. Le sucedió Abelardo Novo Brocas diez días después de los sucesos del 14 de marzo. GIL ANDRÉS, 2000: 249 y 252 .

${ }_{19}$ De «irritación» habla BAHAMONDE, 41/1 (Madrid, 2011): 72, que glosa el parte. Comunicado de Guerra, en CRUZ, 2006: 208. ALCALÁ-ZAMORA, 2011: 296. 
primavera, a mediados de mayo, se produjo un grave enfrentamiento en las calles de la vecina localidad de Alcalá de Henares, que, como veremos, tiene importantes similitudes con el de Logroño. Aquí residían más de un millar de militares agrupados en varios regimientos $\mathrm{y}$, al igual que en otros casos donde había cuarteles, la primavera de Alcalá no transcurrió con normalidad. Es más, lo de mayo alcanzó una enorme repercusión nacional, tanto en el ámbito castrense como en el de la política parlamentaria. Lo relevante, en todo caso, es que la documentación disponible nos permite reconstruir casi al minuto lo que pasó en esta pequeña localidad situada al noreste de la capital; $y$, como se verá, entender mediante un caso concreto el contexto en el que surgió el enfrentamiento y los motivos por los que trascendió de un simple episodio local. Además, nos puede ayudar a conocer con mayor precisión cómo se vivieron en las localidades con fuerte presencia militar esos conflictos en las calles que algunos oficiales interpretaron como una quiebra del principio de jerarquía y autoridad que se ha mencionado más arriba, o incluso que fueron utilizados por quienes conspiraban contra el gobierno del Frente Popular como una muestra de lo que describían en su correspondencia privada como una «situación general» de «confusión»y «anarquía latente» que, según ellos, estaba destruyendo al país ${ }^{20}$.

\section{En las Cortes: «Lo de Alcalá ya lo veremos»}

El día 19 de mayo se celebró una importante sesión en las Cortes. Azaña, recién ascendido a la Presidencia de la República, acababa de confiar la formación de un nuevo gobierno a Santiago Casares Quiroga. Este se presentaba en el hemiciclo para hacer una extensa declaración ministerial. Dada la delicada situación del orden público, había mucha expectación sobre lo que pudiera decir. Sin embargo, el nuevo presidente centró buena parte de su intervención en otras cuestiones. Y sólo al final hizo una declaración expresa de que su Gobierno no iba a tolerar que los enemigos de la República pusieran contra las cuerdas al régimen; él no ocultaba, al contrario, que sería «beligerante» contra «el fascismo», según dijo exactamente ${ }^{21}$. Pese a la contundencia de la expresión, no quedó claro que esto fuera suficiente para ganarse el favor de las izquierdas obreras, entre las que Casares no era bien considerado. Tampoco las

${ }^{20}$ Carta de Fidel de la Cuerda Fernández, militar del Arma de Infantería, al general Sanjurjo, Madrid, 4-6-1936, en AJS.

${ }^{21}$ Las palabras de Casares fueron estas: «Cuando se trata de implantar en España un sistema que va contra la República democrática y contra todas aquellas conquistas que hemos realizado en compañía del proletariado, ¡ah!, yo no sé permanecer al margen de esas luchas y os manifiesto, señores del Frente Popular, que contra el fascismo el Gobierno es beligerante. (Muy bien.)». Diario de Sesiones de las Cortes (DSC), 29, 19-5-1936: 693-698. 
derechas estaban predispuestas favorablemente, pues le acusaban de haber sido un ministro de la Gobernación profundamente parcial durante las semanas pre$\operatorname{vias}^{22}$.

Aunque había rumores de que el nuevo jefe de gobierno daría explicaciones sobre algunos episodios inquietantes de indisciplina militar en guarniciones próximas a Madrid, Casares no dijo nada al respecto. Tras él intervino Gil-Robles, que además de censurarlo, adoptó un tono defensivo, dedicando buena parte de su tiempo a explicar por qué su partido no podía «sentir entusiasmo ni concomitancias con la ideología fascista». Pero no fue el jefe de la CEDA, sino el del Bloque Nacional, el monárquico Calvo Sotelo, el que aprovechó para atacar con dureza al gobierno con motivo de la gestión del orden público y, a propósito de este asunto, meter el dedo en la herida y sacar a relucir el problema de los cuarteles y la política militar. Calvo espetó a Casares con el tono que le caracterizaría en esos meses: «Se están esfumando el sentido de la responsabilidad, el principio de la jerarquía y, sobre todo, el concepto de la autoridad». Y justo en ese momento, en un ambiente cada vez más caldeado, cuando aseguraba que «podría presentar algunos casos en demostración de esto que afirmo», le interrumpió el diputado socialista por Jaén, Tomás Álvarez Angulo, que sólo dijo una palabra: «Alcalá». Y de inmediato otro diputado, probablemente conservador, añadió: «Lo de Alcalá ya lo veremos». Siguieron «rumores» e intercambios de palabras que el Diario de Sesiones, como era habitual cuando había graves trifulcas, no recogió.

De momento, esa referencia a Alcalá quedó en nada. Casares no había hecho mención alguna a problemas en los regimientos de esa ciudad. Calvo Sotelo tampoco siguió con ese caso, aunque sí continuó su ataque al nuevo presidente echándole en cara que, tras la remodelación del gabinete, fuera él quien controlara directamente el Ministerio de la Guerra. A decir del líder monárquico, un general estaría en mejores condiciones para mantener la disciplina en unos momentos como aquéllos, pero Casares habría preferido amarrar el departamento para proceder con más determinación a las depuraciones. Y no se quedó ahí; por si alguna de sus palabras sobre una posible acción militar por culpa del orden público no fuera suficientes, añadió lo siguiente, para gran escándalo de la Cámara: «iAutoridad en los cuartos de banderas! Evidente; pero también autoridad en la calle. Yo aprendí el concepto de autoridad al lado de un maestro cuya memoria honraré siempre: el general Primo de Rivera. (Protestas) $)^{23}$.

${ }^{22}$ Las derechas lo acusaban de no haber impedido la violencia anticlerical desencadenada en Madrid entre los días 3 y 5 de mayo, a pesar de tener información previa sobre los instigadores. GONZÁLEZ GULLÓN, 2011: 399-408. ÁLVAREZ TARDÍO y VILLA GARCÍA, 132 (Madrid, 2013): 715-717.

${ }^{23}$ DSC, 29, 19-5-1936: 697-698 y 704-705.

Hispania, 2019, vol. LXXIX, nº 263, septiembre-diciembre, págs. 757-784, ISSN: 0018-2141, e-ISSN: 1988-8368 https://doi.org/10.3989/hispania.2019.019 
Como era de esperar, si la situación era ya tensa, esta afirmación provocó un cruce de insultos y gritos que la Presidencia tardó en sofocar. Pero ¿qué había pasado en Alcalá, y por qué salía a relucir en un debate sobre política nacional, orden público y disciplina militar? Y, no menos relevante, ¿por qué Casares no quería hablar de ello?

Una pista la proporcionó de inmediato el diputado comunista Uribe, que intervino para explicar su apoyo condicionado el nuevo Gobierno y para denunciar que «el panorama» presentado por Gil-Robles y Calvo Sotelo era «interesado», el propio de quienes defendían «ideas reaccionarias y fascistas». Negó que el problema para el Gobierno y el orden público fuera el «proletariado» e identificó el riesgo en quienes «sabotean y torpedean todas las instituciones democráticas de la República». Se refería a los jueces, pero también, y especialmente, a los militares: «Es precisamente a cuenta de las actividades de algunos elementos del Ejército, donde radica uno de los peligros fundamentales para la República». Y para ilustrarlo añadió algún detalle a la referencia anterior a Alcalá: ahí «tenemos los hechos de Alcalá de Henares, donde partes importantísimas de la oficialidad y del mando del Ejército se niegan en redondo a acatar las órdenes de las autoridades legítimas, de las autoridades militares». No faltó tiempo al diputado por Madrid de la CEDA, Rafael Esparza, vecino de Alcalá de Henares, para interrumpirle con un: «Eso no es exacto», iniciándose de nuevo los «rumores» en el hemiciclo. Pero Uribe no se sintió presionado, al contrario, pues añadió algo que proporcionaba una pista sobre lo que había pasado en esa localidad antes de la indisciplina militar que él denunciaba: «Hay otros organismos del Estado sobre los cuales es necesario que entre la verdadera acción del pueblo para limpiarlos de toda la carroña que está metida allí desde hace muchos años.» Es decir, si el Gobierno no actuaba estaría justificado que el «pueblo» lo hiciera por su cuenta y plantara cara a los militares antirrepublicanos. En Alcalá, por lo que parece, algo de esto había habido... Casares, en todo caso, no se pronunción ${ }^{24}$.

Por consiguiente, el eco de los sucesos ocurridos en Alcalá de Henares cuatro días antes retumbó en el hemiciclo del Congreso. Sin duda, lo que fuera había sido algo más que uno de los muchos episodios de violencia que habían amargado la vuelta al poder de la izquierda republicana a partir del 20 de febrero $^{25}$. Si había salido en el debate de presentación del nuevo Gobierno era, como se verá, porque lo ocurrido había impactado en la política nacional, esto es, había puesto contra las cuerdas a las autoridades y había contribuido a acrecentar la tensión entre una parte del Ejército y el ejecutivo.

\footnotetext{
${ }^{24}$ DSC, 29, 19-5-1936: 717.

25 Violencia tras el regreso de Azaña al gobierno, en ÁLVAREZ TARDÍO y VILLA GARCÍA, 2017: 329-351.
}

Hispania, 2019, vol. LXXIX, nº 263, septiembre-diciembre, págs. 757-784, ISSN: 0018-2141, e-ISSN: 1988-8368 https://doi.org/10.3989/hispania.2019.019 


\section{El fin de una Calma tensa}

Alcalá de Henares era una población pequeña situada a treinta kilómetros al noreste de Madrid por la carretera de Barcelona. Después de un lento pero implacable declive, se había convertido en un sitio donde predominaban las labores agrícolas de los alrededores, con una actividad industrial y comercial menor, exceptuando alguna fábrica de cerámicas y otra de mantenimiento ferroviario. Eso sí, conservaba un rasgo de su identidad pasada, la presencia de numerosos conventos e iglesias, con una población religiosa notable; pero, sobre todo, contaba con un acuartelamiento que daba a la ciudad complutense el aspecto de una plaza militar.

Las elecciones de febrero de 1936 habían estado muy reñidas en Alcalá, con un resultado prácticamente igualado entre las fuerzas conservadoras, lideradas por una CEDA de reciente creación, impulsada después de octubre de 1934, y las frentepopulistas, donde, a pesar de tratarse de la ciudad natal de Azaña, mandaban por mucha diferencia los socialistas. Apenas unas decenas de votos habían inclinado la balanza del lado izquierdista. Como en otras partes de España, durante el recuento se habían sucedido concentraciones de celebración, empañadas por algunas violencias. Del mismo modo, a las pocas horas de cambiar el gobierno nacional, la gestora municipal, nombrada tras la huelga de octubre de 1934, había cesado y la coalición de socialistas y republicanos de izquierdas había recuperado el ayuntamiento, si bien su mayoría se debía más a la incomparecencia de sus adversarios que a un aplastante dominio del voto municipal; no en vano, desde abril de 1931 no se había vuelto a elegir concejales y el grupo mayoritario, el que controlaba de facto el gobierno municipal aunque no representara una mayoría absoluta de los concejales, era el de los socialistas $^{26}$.

Durante las semanas siguientes las elevadas expectativas - $-\mathrm{y}$, entre los perdedores, inquietud - que generó el cambio provocaron algunos problemas de convivencia. El más significativo ocurrió entre el 4 y el 6 de marzo, cuando un choque entre jóvenes socialistas y derechistas dio lugar a la detención de casi todos los dirigentes conservadores de la localidad, una huelga general y episodios de violencia muy graves. En esas circunstancias, el nuevo alcalde de la izquierda republicana, receloso de usar a la policía para detener la violencia iniciada por algunos jóvenes de la Casa del Pueblo, acabó recurriendo al comandante militar de la plaza. Una vez más y como era demasiado habitual en las localidades con acuartelamientos, los soldados salieron a la calle para poner orden y evitar que una huelga general sustanciada con incendios de iglesias y

${ }^{26}$ Resultados electorales, en Boletín Oficial de la Provincia de Madrid, 18-2-1936. Violencias, en Eco de Alcalá (Alcalá de Henares), 29-2-1936. Acta de la sesión del pleno municipal de 21 de febrero, en AHMAH, Signatura 11066/2. 
asaltos a algunos domicilios particulares fuera a más, ante rumores de que se preparaba una insurrección mayor con apoyos procedentes de la capital. Los militares no tuvieron que pegar ni un solo tiro; bastó su presencia en las calles para calmar los ánimos. Pero los socialistas, que tenían la minoría mayoritaria de concejales y controlaban el pleno municipal, no dieron por buena la decisión del alcalde y le exigieron explicaciones por la presencia del Ejército en las calles. Juan Antonio Cumplido, que así se llamaba el regidor, además de amigo de Azaña, era un republicano confundido y sobrepasado por la presión de sus socios obreros. Estos se preparaban para unas elecciones municipales inminentes y aspiraban a reducir significativamente la competencia, con sus rivales derechistas amedrentados y recluidos en sus casas, y la izquierda republicana desbordada por la movilización obrera ${ }^{27}$.

En ese contexto, a finales de marzo, unas semanas después de los citados sucesos, la minoría socialista presentó y aprobó por unanimidad un escrito que constituía «un voto de censura» contra la actuación del alcalde durante las jornadas del 4 a 6 de marzo. Habrían de pasar todavía algunas semanas, pero, finalmente, el 24 de abril el socialista Pedro Blas se hizo con la alcaldía gracias al voto de sus nueve compañeros de minoría y sin ninguna oposición. Para entonces, el gobierno nacional ya había anunciado que las elecciones municipales quedaban suspendidas sine $d_{i} e^{28}$.

Llegó mayo y una noticia nacional impactó en la ciudad, no sin motivos. Su ilustre convecino, Manuel Azaña, había ascendido a la Presidencia de la República. El nuevo alcalde socialista habló por la radio local para anunciar que era «justo» que «la ciudad entera», «sin distinción de ideas políticas, en puro ambiente de franca cordialidad» se asociara a «este hecho histórico nacional con manifestaciones de público regocijo (...), al ocupar un alcalaíno la regencia de la República». Se declaró un día festivo, se ordenó que los balcones se engalanaran con «colgaduras» y se preparó una verbena celebratoria ${ }^{29}$.

Los festejos coincidieron con la celebración de San Isidro. Los católicos locales organizaron su romería tradicional a la ermita del santo, casi a la par que los simpatizantes del Frente Popular celebraban el ascenso de Azaña. Amén de colocar a los pies de la estatua de Cervantes, en la plaza principal de la localidad, una «gran corona de laurel, con una fotografía, de gran tamaño, del señor Azaña», en todos los edificios públicos, incluidos los militares, ondeó «el pabellón nacional». Por su parte, los jóvenes socialistas y comunistas de la

27 ÁlVAREZ TARDÍO, 7 (Toledo, 2018): 327-330. Sobre la política local antes de 1936, véase LLEDÓ, 1997. La izquierda obrera alcalaína, en VADILLO MUÑOZ, 2013.

${ }_{28}$ Actas de las sesiones del pleno municipal de 27 de marzo y 24 de abril, AHMAH, Signatura 11066/2. Eco de Alcalá, 22-4-1936. Decreto de aplazamiento de las elecciones, en $A B C$ (Madrid), 4-4-1936.

${ }^{29}$ La Vanguardia (Barcelona), 12-5-1936. 
localidad, recién fusionados en una sola agrupación, organizaron un acto propio en el que, como si quisieran hacer patente su recuperación de las calles, desfilaron «con sus correspondientes uniformes» por todo el centro, poco antes de que una banda de música diera un concierto y se lanzara al cielo «una bonita colección de fuegos artificiales $\rangle^{30}$.

A decir de los medios, la «tranquilidad fue completa» en esas jornadas, «no registrándose el menor incidente». Aunque fue más bien una calma engañosa, lograda simplemente por la incomparecencia de los jóvenes derechistas en las calles. Porque lo cierto es que pocas horas más tarde, el día 15, tras la celebración de la romería de San Isidro, la situación tomó un rumbo inesperado.

Ese día todavía resonaba el eco de las celebraciones por el nombramiento de Azaña. Y algunos socialistas no parecían dispuestos a dar por finiquitado el entusiasmo popular, más todavía en unas horas en las que los derechistas, aprovechando un acto religioso, volvían a las calles. Por eso, para «contrarrestar la fiesta religiosa» se decidió continuar con el homenaje público al nuevo presidente de la República. Siguió la «música» y la «alegría» de las horas previas. Durante las mismas, un paisano llamado Pedro López, (apodado «el Berruga»), un personaje muy popular y «aficionado a la bebida», tuvo un accidente $\mathrm{y}$, después de una violenta caída, resultó herido en la frente y sangró «en abundancia». Cuando por fin logró regresar a su casa, debió de excusarse ante su mujer asegurando que había sido objeto de una agresión. Y ésta, a su vez, poniendo «los gritos en el cielo» le contó a su hermana que un grupo de fascistas habían pegado a su marido. De ahí se propagó un rumor, que sin duda tuvo cómplices interesados entre los jóvenes izquierdistas, según el cual se llegó a decir que «el Berruga» había quedado «moribundo», incluso que estaba muerto ${ }^{31}$.

No es difícil entrever la finalidad de quienes propagaron el rumor: animar un ajuste de cuentas con algunos jóvenes de AP, «fascistas» en boca de sus adversarios de las Juventudes Socialistas Unificadas (JSU), con los que ya habían tenido varios enfrentamientos con anterioridad, y especialmente durante los susodichos sucesos de marzo. Además, como en otras localidades del país, durante aquella primavera fueron constantes en Alcalá las denuncias de las izquierdas contra la posesión de armas por parte de las derechas, a las que se acusaba de no haber aceptado el resultado electoral y a las que se quería hacer pagar por la «represión» del llamado bienio negro.

${ }^{30}$ La Vanguardia, 12-5-1936.

${ }^{31}$ Relato minucioso del periodista de izquierdas Antonio Uriel, enviado a Alcalá por el jefe de redacción de El Heraldo (Madrid), y que siguió los hechos hora a hora. La crónica fue censurada, pero se trata de una descripción detallada y bastante objetiva, aun cuando su jefe y el medio para el que trabajaban eran firmes partidarios del ala más radical de la izquierda republicana. No cabe, por tanto, sospechar una mala intención en esta cruda realidad del rumor inventado a partir de la caída del «Berruga». MUÑIZ, 2009: 235. 
Inflamados por el rumor de que «Perico el Berruga» estaba moribundo, varios jóvenes izquierdistas se aprestaron a tomarse la justicia por su mano. Sabían que sus rivales habían participado en la romería y les esperaron en el entorno de la plaza de Cervantes. No fue un encuentro casual; tenían bien identificados sus objetivos. Entre ellos, uno de los japistas locales con el que mantenían cuentas pendientes desde las violentas jornadas de primeros de marzo, si no antes: Nicolás Yuste.

Cuando este último y su amigo Carlos Bellido pasaban por la calle Mayor, varios jóvenes de significación contraria se acercaron y los agredieron bajo la acusación de haber maltratado al «Berruga». Mientras un grupo numeroso jaleaba a los agresores, estos consiguieron escapar en dirección al puesto de la Cruz Roja. Ambos fueron atendidos de heridas producidas por un objeto metálico; pero no acabó ahí la persecución, pues un grupo de izquierdistas rodeó el local con la intención de asaltarlo y terminar el ajuste. Hubo, pues, que esperar a la presencia de varios guardias de Asalto para que los dos japistas pudieran regresar a sus casas, escoltados y todavía en presencia de numerosos concentrados en actitud amenazante ${ }^{32}$.

\section{4. «AHÍ VAN ESOS CHULOS»: EL ENFRENTAMIENTO ENTRE OFICIALES E IZQUIERDISTAS}

Este episodio, tan poco excepcional en esos días entre jóvenes de ideologías contrarias, podía haber quedado en poco más que una agresión, pero derivó en otro conflicto de consecuencias mayores. A Yuste le acompañaban también «unas muchachas» que se cruzaron con militares del Regimiento de Caballería justo cuando aquél, sangrando abundantemente por la cabeza, se encaminaba a toda prisa al puesto de la Cruz Roja. Entre sollozos, las jóvenes pidieron amparo a los tres oficiales, el teniente Rafael de Mendizábal Amezaga, el teniente Antonio de Alos Herrero y el capitán Luis Jover Peña, de 25, 23 y 42 años respectivamente, que en se momento se encaminaban al Casino para cenar.

No parece que estos se lo pensaran mucho, tal vez demasiado acostumbrados a dirimir los conflictos entre los civiles apelando a una autoridad militar que, hasta hacía poco, nadie había puesto en cuestión. Fuera por eso, o por probable simpatía hacia los japistas, lo cierto es que se acercaron de inmediato hasta donde estaban los agresores para recriminarles su acción. Lo que no esperaban es lo que pasó a continuación, esto es, que lejos de amedrentarse ante los oficiales, los jóvenes izquierdistas los rodearon y un grupo cada vez

32 Declaraciones de C. Bellido, N. Yuste y A. Rojo, Sumario 219/1936, criminal de oficio, causa con motivo de disparos y lesiones, Tribunal de Urgencia, AGA (7) 42.1, 44/14734. Y MUÑIZ, 2009: 235.

Hispania, 2019, vol. LXXIX, nº 263, septiembre-diciembre, págs. 757-784, ISSN: 0018-2141, e-ISSN: 1988-8368 https://doi.org/10.3989/hispania.2019.019 
más numeroso de personas empezó a insultarlos y reprocharles que intentaran proteger a los «fascistas».

La situación se tornó peligrosa porque, amén de crecer el número de concentrados, también aparecieron los guardias municipales y el capitán Jover les echó en cara no haber protegido a Yuste, creciendo la tensión. Advertidos de lo que estaba ocurriendo por la alcaldía - donde, al parecer, había llegado a penetrar un teniente empuñando un arma y descargando su ira contra el regidor socialista - , llegaron los dos coroneles que estaban al mando de los regimientos, Moreno y Gete. Su aparición en la plaza fue providencial porque ya uno de los tenientes, sintiéndose acorralado, había sacado su pistola y era evidente que los guardias municipales allí presentes estaban dispuestos a responder. El coronel Moreno ordenó a los oficiales que le entregaran sus pistolas y que se retiraran al cuartel, lo que contrarió profundamente a sus subordinados pero despertó un encendido elogio de quienes les rodeaban. Todavía hubieron de pasar algunos minutos de grave tensión, en los que se oían numerosos gritos de «fascistas» y «cabrones», a la par que se jaleaba la actitud del coronel Moreno. Al final, después de un enfrentamiento entre un comandante y un izquierdista que le había levantado el puño en señal de amenaza, los coroneles lograron que los oficiales se retiraran sin que se desatara un trágico enfrentamiento ${ }^{33}$.

Pero la calma duró poco. Dentro del cuartel habían llegado noticias de lo que ocurría en el exterior y algunos oficiales se habían soliviantado hasta el extremo de querer salir en auxilio de sus compañeros, contraviniendo las órdenes de sus superiores. Hubo dos que reaccionaron impulsivamente cuando supieron, por boca del teniente Mendizábal, que el coronel les había impedido defenderse de los insultos y amenazas. Fueron el teniente Manuel Isasa Navarro y el capitán José Manuel Rubio Alonso, ambos de 24 años, que salieron entonces del cuartel. Cuando llegaron a la plaza de Cervantes, epicentro de los altercados, se toparon con grupos de izquierdistas que, a la altura de un céntrico hotel de la localidad, empezaron a decir en alta voz: «Ahí van esos chulos». Al poco, la tensión creció y mientras Isasa lograba regresar hacia al cuartel, el capitán Rubio se vio acosado y amenazado. Se montó entonces en su bicicleta y huyó rápidamente en dirección a su domicilio. No está del todo claro si justo antes de empezar su huida hubo o no disparos, pero sí consta que algunos empezaron a gritar: «Ahí va un Capitán; vamos a élı ${ }^{34}$.

Como pudo constatar el periodista de El Heraldo y confirmaron algunos de los testigos que declararon ante el juez, «un grupo de obreros» que acababa de salir de la fábrica de cerámica local y tomaba algo en «la taberna del Cea»

${ }_{33}$ Declaraciones de L. Jover, R. de Mendizábal y A. de Alos, AGA (7) 42.1, 44/14734. En las declaraciones judiciales no hay rastro de la incursión de un oficial en el ayuntamiento para amenazar al alcalde; esta información procede de MUÑIZ, 2009: 236.

${ }^{34}$ Declaraciones de M. Isasa, J. M. Rubio y P. D. Solís, AGA (7) 42.1, 44/14734. 
intentó agredir a Rubio. Puede que el capitán hiciera «un gesto despectivo» o que fueran «los proletarios quienes le insultar[a]n». En todo caso, después de conseguir «golpearle», este logró huir por la calle Mayor. Los demás le siguieron corriendo y gritando «a ese», «cogedle», logrando así que otros jóvenes izquierdistas, como Bonifacio Peña, de 26 años, se unieran a la persecución. Parece que durante la misma se produjo un primer intercambio de disparos, aunque no está claro si Rubio, que desenfundó su arma, fue el primero en disparar. No obstante, lo seguro es que no lograron detenerle, pues llegó a su casa ileso y logró refugiarse en el interior ${ }^{35}$.

Acto seguido un nutrido grupo de personas, algunas armadas, rodearon la casa del capitán. Algunos vecinos les jaleaban para que acabaran con el oficial, tachado de fascista. Cada vez que un nuevo individuo se incorporaba al grupo se podía oír la consigna: «U.H.P». Entre Rubio y los concentrados se inició entonces un intercambio de disparos. A la vista de la resistencia encontrada y de que el capitán Rubio hirió con una escopeta de perdigones a algunos de los que rodeaban su casa, varios izquierdistas se dirigieron a por líquido inflamable para quemar la vivienda. Minutos más tarde, sin que apareciera ni la guardia de asalto ni nadie del puesto de la guardia civil, al ver que prendían su puerta, Rubio logró huir, junto con su mujer e hijos, por el patio trasero. Tampoco podía esperar que sus compañeros del regimiento vinieran a ayudarle porque, como supo el teniente Isasa cuando regresó al cuartel y advirtió de que Rubio corría peligro, las órdenes de sus superiores eran «de que no saliera ningún oficial del Cuartel». De entre las varias decenas de personas que rodeaban la casa hubo algunos heridos de bala, incluido el citado Bonifacio y otro llamado Esteban Pardo. En cuanto al capitán, logró llegar hasta una carretera cercana, donde fue amparado por una camioneta de guardias de asalto. Estos le condujeron al cuartel, aunque todavía hubo algunos problemas más en el trayecto porque un «numeroso» grupo de izquierdistas, muy excitados ya por los episodios anteriores y porque Rubio había herido a varios de sus compañeros, increparon a los guardias exigiendo que se le fusilara allí mismo ${ }^{36}$.

El reportero especial enviado por El Heraldo pudo comprobar algo que, horas más tarde, certificaría el perito del juzgado: pese a que los «trabajadores afirman que no dispararon contra el capitán Rubio», era «evidente», escribió el periodista, «que en la fachada del domicilio del oficial hay muchos impactos.»

${ }^{35}$ Entrecomillados, en la declaración de Bonifacio Peña, el joven izquierdista que resultó herido de mayor gravedad, y en MUÑIZ, 2009: 236. Rubio admitió haber sacado su arma, aunque aseguró que le perseguía gente armada y que oyó al menos un disparo realizado contra él desde los soportales de la calle Mayor. Declaraciones de Peña y Rubio, AGA (7) 42.1, 44/14734.

${ }^{36}$ Declaraciones de B. Peña, E. Cogollar, J. Molina, M. Isasa, J. M. Rubio y del ayudante del capitán Rubio, que estaba en casa de este último cuando Rubio se refugió tras su accidentada huida, en Declaraciones de Peña y Rubio, AGA (7) 42.1, 44/14734. 
El alguacil, de hecho, certificó la existencia de varios «impactos de proyectiles de armas de fuego» sobre el muro de la casa — es decir, realizados por quienes la rodeaban con intención de asaltarla - y de manchas de «humo» o «chamuscamiento» en la puerta ${ }^{37}$.

\section{Consecuencias inesperadas}

El balance de todo lo sucedido desde última hora de la tarde, nada más acabar la romería, fue de 8 heridos, cuya edad media era de 23 años, sin que ninguno pasara, significativamente, de los 27: los dos japistas agredidos en la plaza y otros seis jóvenes izquierdistas, dos de ellos graves. El suceso podría haber sido uno más de los graves episodios de violencia que se registraron en esos meses, aunque con la importante particularidad de que se vieron involucrados oficiales del Ejército. Sin embargo, no terminó con el intento frustrado de linchamiento del capitán Rubio. La orden dada en los cuarteles de no salir en ayuda de este último provocó un gran alboroto entre algunos compañeros. La situación se descontroló hasta el punto de que, horas más tarde, en los círculos de la prensa de Madrid se comentaba «el rumor inquietante de haber ocurrido hechos graves en Alcalá de Henares»; y la mañana del día 18 se decía que «las habladurías generales» — según anotaba Muñiz en su diario- «centran ya los sucesos en el marco de una sublevación militar, que les da relieve de mayor importancia $\rangle^{38}$.

¿Qué había pasado entre la noche del 15 y la mañana del 18 para que el choque entre los jóvenes de la JSU complutense y los oficiales derivara en un rumor de sublevación militar, y llegara incluso a mencionarse en el debate parlamentario?

Los refuerzos de guardias de asalto tardaron en llegar desde Madrid. La calma en la ciudad era tensa. A partir del día 16 lo que más preocupó al recién estrenado Gobierno de Casares no fue un posible rebrote de la violencia entre jóvenes izquierdistas y oficiales, sino cómo prevenir un problema más grave con la guarnición local. Sin duda, dentro de los cuarteles se vivieron momentos de mucha excitación, con algunos oficiales totalmente contrariados por la decisión de no acudir en auxilio de su compañero, para ellos una rendición humillante que sentaba un peligroso precedente en sus ya deterioradas relaciones con la izquierda obrera local. Y así pronto se propagaron rumores por la ciudad de que podía producirse una acción militar. Según la versión que el alcalde socialista trasladó al gobernador, desde «las primeras horas del día 17» se habían repartido «profusamente hojas clandestinas en el interior de los

\footnotetext{
37 MUÑIZ, 2009: 237. Informe del alguacil, en AGA (7) 42.1, 44/14734.

38 Anotación de 18 de mayo, en MUÑIZ, 2009: 234.
} 
cuarteles» incitando «a las tropas para que se apoderasen de los mandos de la nación por la fuerza de las armas». No podemos saber por otras fuentes si el alcalde dijo o no la verdad, aunque hay algunos indicios para suponer que exageró ante el gobernador para justificar la reacción de la Casa del Pueblo en esas horas, que amenazó con una nueva huelga general; y esto era muy importante porque aumentaba la probabilidad de que se repitieran las graves violencias e incendios vividos en la ciudad a primeros de marzo, cuando también se había declarado un paro general. Lo de las «hojas clandestinas» difícilmente pudo ser algo más que un rumor, aunque sí parece que hubo algo que excitó a la opinión izquierdista local y le animó a declarar la huelga y exigir medidas rápidas contra los oficiales: sabemos, por una carta privada de un militar del arma de Artillería, que el día 16, después del intento de asalto a la casa del capitán Rubio y de la humillación de no haber podido salir en su defensa, algunos oficiales «se cobraron repartiendo palos entre los que se habían significado como atacantes $\rangle^{39}$. Este dato, más que la construcción a posteriori de rumores sobre «hojas clandestinas» e incitación a la rebelión, es lo que podría explicar la reacción inmediata de la Casa del Pueblo. Sus dirigentes amenazaron a las autoridades con una nueva huelga general si no adoptaban rápidas y enérgicas medidas; y lo que es más importante, a cambio de no declararla exigieron el traslado inmediato de los dos regimientos de Caballería implicados, es decir, que el Gobierno castigara a los militares como responsables de lo ocurrido.

De este modo, no está claro si los rumores de una sublevación militar inminente fueron el fruto de movimientos reales dentro de los cuarteles o una fabulación de los dirigentes de la Casa del Pueblo para presionar a favor del traslado de las tropas y presentar, así, lo ocurrido el día anterior como un episodio más de una lucha defensiva contra los «fascistas». El ministro de la Guerra, no obstante, tomó una decisión rápida, sin esperar a una investigación. Para sorpresa de los coroneles que habían mediado la tarde del 15, se ordenó el traslado inmediato de los dos regimientos, Villarobledo y Calatrava, a Palencia y Salamanca, respectivamente. La orden que se cursó era de aplicación tan inminente que obligaba a los oficiales a dejar a sus familias en Alcalá, lo que para ellos constituía un motivo más de preocupación porque temían ulteriores agresiones en sus domicilios como la ocurrida en casa del capitán Rubio. Entre esto último y las muestras de indisciplina que debieron de darse dentro del cuartel, el Gobierno sabía que no podría hacer cumplir sus órdenes sin un grave riesgo de insubordinación. Por eso mismo desplegó numerosos efectivos de la guardia de asalto y estableció «un servicio especial de vigilancia, con las motos, a lo largo de la carretera» que unía Alcalá con la capital. No en vano, durante la madrugada del día 18 Casares supo que el grueso de oficiales de los dos regimientos

39 «Repartiendo palos», en Carta de Fidel de la Cuerda Fernández a Sanjurjo, Madrid, 4-6-1936, AJS. Versión del alcalde, en MUÑIZ, 2009: 240.

Hispania, 2019, vol. LXXIX, nº 263, septiembre-diciembre, págs. 757-784, ISSN: 0018-2141, e-ISSN: 1988-8368 https://doi.org/10.3989/hispania.2019.019 
se negaba a cumplir las órdenes de traslado y que ningún mando, empezando por los coroneles o el comandante, se quería poner al frente para obligar a sus subordinados. El general Alcázar, comandante de la plaza, lo comprobó en el cuartel sobre las tres de la madrugada. Acto seguido se dirigió al teniente de Asalto que dirigía las fuerzas policiales y constató su impotencia: «El primer regimiento de caballería se niega a salir. Por consiguiente, yo no tengo nada que hacer aquí. La fuerza la tienen ustedes, que desde este momento se encargarán de mantener el orden.» Fue a partir de ese momento cuando numerosas camionetas de Asaltos se trasladaron desde Madrid para hacer cumplir las órdenes del Gobierno. Llegaron a primera hora de la mañana. También lo hicieron los generales Peña y Miaja. El primero, «como jefe de la división de Caballería se encaminó a los cuarteles» y «mandó formar a las tropas», comprobando que, «desde el coronel al último cabo», ninguno de los oficiales quería hacerse cargo de mandar a sus compañeros para iniciar al traslado ordenado por Casares. El Gobierno, una vez informado, dispuso que los guardias de asalto procedieran al arresto, uno a uno, de todos los oficiales. Pocas horas más tarde varias camionetas de los guardias de asalto empezaron a trasladar a los detenidos a la prisión de Guadalajara. El alcalde pudo respirar entonces tranquilo porque no se había cumplido la amenaza de huelga general y porque se había cortado lo que, para él, había sido un peligroso intento de insubordinación militar ${ }^{40}$.

No hay duda de que los jóvenes izquierdistas fueron los responsables del inicio de la violencia durante la jornada de San Isidro en Alcalá de Henares. O el ministro no fue bien informado, o simplemente hizo caso omiso de las circunstancias que rodearon el ataque contra el capitán Rubio, así como el hecho de que el coronel Moreno había evitado una desgracia minutos antes. ¿Por qué el Gobierno decidió castigar sólo a los militares y no a las organizaciones que amparaban la violencia juvenil en las calles? Casares — que, como se recordará, había asumido personalmente la cartera de Guerra-, se encontró con un problema muy grave dentro de dos regimientos próximos a la capital. Acababa de estrenarse como presidente del Consejo y, como se vería de inmediato en las Cortes, sus socios de la izquierda obrera no le exigían beligerancia contra sus radicalizadas juventudes sino contra el fascismo, y le pedían que fuera contundente y rápido contra lo que ellos identificaban como principales peligros de la nueva etapa política: esos «organismos del Estado», el Ejército especialmente, en los que, en palabras ya comentadas del diputado Uribe, era necesario limpiar «toda la carroña que está metida allí desde hace muchos años» ${ }^{41}$.

En tales circunstancias, no se informó a la prensa del alcance de lo ocurrido, aunque trascendió que el Consejo de Ministros del día 18 había tratado sobre

\footnotetext{
40 Entrecomillados, en MUÑIZ, 2009: 237-238.

${ }^{41}$ Palabras ya citadas más arriba, en $D S C, 29,19-5-1936: 717$.
}

Hispania, 2019, vol. LXXIX, nº 263, septiembre-diciembre, págs. 757-784, ISSN: 0018-2141, e-ISSN: 1988-8368 https://doi.org/10.3989/hispania.2019.019 
«los hechos mismos acaecidos hoy en Alcalá de Henares» ${ }^{42}$. Eran, además, unas semanas, en las que circulaban por doquier rumores de conspiración militar, lo que hacía todavía más difícil la posición de Casares. Ciertamente, algunos oficiales de los regimientos alcalaínos se habían negado a cumplir órdenes $\mathrm{e}$, incluso, parece que se habían tomado la justicia por su mano al día siguiente del asalto en la casa del capitán Rubio, lo que sin duda justificaba la adopción de medidas disciplinarias. Por no hablar, además, de que, como sabía el Gobierno, algunos de esos militares habían sido castigados anteriormente, con motivo de la sanjurjada de $1932^{43}$. Quizás por todo esto, sumado a la presión de sus socios parlamentarios, Casares decidió actuar con tanta celeridad; y se negó a dar una oportunidad para que prosperaran las gestiones que realizaban los generales enviados a Alcalá a fin de lograr un traslado menos traumático de los dos regimientos, algo que, al menos, habría permitido que la medida no se interpretara en los cuarteles españoles como un castigo, a la vez que había evitado, de paso, que el gobierno se viera nuevamente acusado de partidismo por la oposición conservadora ${ }^{44}$.

Por último, hay un factor que pudo pesar tanto o más que la indisciplina y los rumores de golpe: si el ministro no hubiera trasladado de inmediato los regimientos y hubiera esperado a los resultados de una investigación interna, se habría tenido que enfrentar a una peligrosa huelga general en una localidad próxima a la capital. Con lo antecedentes de la violencia desatada en Alcalá a primeros de marzo, en medio de otra huelga general parecida, y teniendo en cuenta que Casares debía hacer frente, en unos días, a la confianza del parlamento, debió de pensar que más valía afrontar la crítica conservadora y el enfado del estamento militar que provocar un grave enfrentamiento con sus socios obreros y arriesgarse a un choque armado entre izquierdistas y soldados en la ciudad del Henares.

Al final, el precio por neutralizar la amenaza de su izquierda y cortar radicalmente la indisciplina de los oficiales alcalaínos, fue, como era previsible, el de alimentar la opinión derechista de que el nuevo ejecutivo no era imparcial y sacrificaba el honor de los militares en el altar de una lucha genérica contra el fascismo. Por eso, el eco de los sucesos de Alcalá llegó al parlamento. Y tuvo, además, repercusión entre los círculos de la conspiración militar; pero no sólo porque el traslado inmediato de los regimientos se considerara un castigo injusto, sino porque de inmediato se sometió a consejo de guerra a los oficiales

${ }^{42}$ La Vanguardia, 19-5-1936.

43 Uriel señaló en su crónica que varios oficiales del regimiento de Caballería habían estado «en Villa Cisneros» y que «otros tomaron [parte] en los sucesos del 10 de agosto», MUÑIZ, 2009: 236.

${ }_{44}$ RIVAS, 1976: 248, aseguró que el gobernador militar solicitó al Gobierno una prórroga para el traslado, a la espera de los resultados de las primeras investigaciones sobre el terreno.

Hispania, 2019, vol. LXXIX, no 263, septiembre-diciembre, págs. 757-784, ISSN: 0018-2141, e-ISSN: 1988-8368 https://doi.org/10.3989/hispania.2019.019 
detenidos. Así, en el entorno del general Sanjurjo los «sucesos de Alcalá» se vieron como un ejemplo de cómo algunos militares, con influencia cerca del ministro de la Guerra, habían boicoteado una salida negociada con los oficiales alcalaínos y habían presionado para el envío inmediato del «general Urbano a instruir expediente sumarísimo» ${ }^{45}$. Como la del alcalde, ésta también era una versión interesada que, si bien acertaba en señalar que la violencia había partido de los jóvenes izquierdistas locales, restaba importancia a la indisciplina mostrada por los oficiales y no calibraba la gravedad que podía alcanzar la situación en Alcalá si el afán de venganza de los oficiales se mezclaba con una declaración de huelga general y una movilización de las izquierdas locales en las calles.

De este modo, al igual que en otros episodios donde se vieron involucrados los militares, como el de Logroño, relatado más arriba, la munición estaba servida para alimentar la opinión (y la propaganda) conservadora en virtud de la cual el gobierno de la izquierda republicana no aplicaba la ley por igual sino en función de quienes se vieran afectados por la misma. Es decir, que la beligerancia contra el fascismo declarada por Casares en las Cortes no implicaba, a ojos de las derechas, igual determinación contra la violencia procedente de los grupos radicalizados de las izquierdas obreras. Por otro lado, no fue menor el impacto que tuvo entre los sectores militares disconformes con la situación política el hecho de que varias decenas de oficiales, empezando por dos coroneles responsables de regimiento, fueran detenidos por guardias de Asalto y trasladados a una prisión militar, dejando, sin embargo, impune la agresión armada contra el capitán Rubio. Así lo dejaba ver la misiva enviada el 23 de junio por el comandante militar de las Islas Canarias, general Franco, al ministro de la Guerra. Su autor se refería abiertamente al «dolor y sentimiento en la colectividad militar» causado por las «noticias de los incidentes de Alcalá de Henares, con sus antecedentes de provocaciones y agresiones por parte de elementos extremistas concatenados con el cambio de guarniciones», reconociendo además que la primera reacción de los «jefes y oficiales», la de «un sentimiento, desgraciada y torpemente exteriorizado, en momentos de ofuscación» había tenido «gravísimas consecuencias» para ellos ${ }^{46}$.

A primeros de junio, sin apenas perder tiempo, los cincuenta y cuatro militares procedentes de los regimientos de Alcalá fueron procesados en un consejo de guerra del que apenas se dieron noticias a la opinión pública, pero que a buen seguro circuló entre los mentideros de la conspiración militar en marcha. Las elevadas penas que se impusieron (12 años de prisión al coronel Gete, para quien la fiscalía pidió la pena de muerte) sugieren tanto que se buscó una respuesta ejemplar por parte de un Gobierno acosado por las conspiraciones,

\footnotetext{
${ }^{45}$ Carta de Fidel de la Cuerda Fernández al general Sanjurjo, Madrid, 4-6-1936, AJS.

${ }^{46}$ Reproducida íntegramente en MARTÍNEZ BARRIO, 1983: 334-335.
} 
como que, efectivamente, algunos oficiales habían violentado gravemente el código militar ${ }^{47}$.

\section{LA ENCRUCiJAda del Gobierno: Un BALANCE}

Hubo más de un millar de episodios de violencia política entre el 16 de febrero y el 17 de julio de 1936. Los estudios más recientes han permitido un avance notable en la cuantificación de esa violencia, aunque es menos acentuado el progreso en el análisis de proximidad ${ }^{48}$. Sabemos, como se señalaba más arriba, que en algunos casos intervinieron efectivos del Ejército, pero nos falta comprender mejor, desde un punto de vista cualitativo, la naturaleza de estos. Ese es el objetivo del análisis que hemos planteado sobre lo ocurrido en Alcalá de Henares. Porque, como muestra este caso y cabe suponer para otros que no conocemos bien, allí donde se vieron involucrados oficiales del Ejército las consecuencias políticas de la violencia en las calles fueron más profundas y prolongadas de lo que parecen a primera vista.

Sería oportunista y simplista sugerir, a la luz del episodio de Alcalá, que la inclinación a favor de la conspiración de algunos oficiales se debió a una percepción creciente de que el Gobierno les impedía hacer valer su autoridad para atajar la violencia en las calles. Esto podría interpretarse equivocadamente como una justificación de su comportamiento. Sin embargo, lo ocurrido en Alcalá muestra un problema subyacente en las relaciones entre el Gobierno y una parte del Ejército, sobre el que la censura evitó una difusión generalizada, que, sin duda, debió de influir en la predisposición de una parte de la oficialía para apoyar el golpe. Porque contribuyó a reforzar una percepción que los conspiradores necesitaban alimentar, esto es, la de que el Gobierno era preso de los sectores radicales de su izquierda con los que había firmado el pacto de Frente Popular; y que, ante una situación como la de Alcalá, aun cuando se demostrara que aquellos se comportaban al margen de la ley para arrinconar a sus adversarios, el ejecutivo, y más concretamente el ministro de la Guerra, sacrificaban el principio de autoridad a las exigencias del contexto político.

Por otra parte, casos como el de Alcalá pusieron contra las cuerdas a un Gobierno de la izquierda republicana presionado en la calle y en el parlamento para que no permitiera que la Justicia o el Ejército fueran refugios de los enemigos de la República. En ese sentido, la encrucijada a la que se enfrentaba Casares era altamente explosiva y muy difícil de afrontar. El embajador británico trasladó a Londres la siguiente reflexión: «Será interesante», escribió el

\footnotetext{
${ }^{47}$ RIVAS, 1976: 248, ya señaló este extremo. Además, La Vanguardia, 9-6-1936.

48 BLÁZQUEZ MIGUEL, 2009. ÁLVAREZ TARDÍO, 48/3 (Cambridge, 2013). GONZÁLEZ CALLEJA, 2015.
}

Hispania, 2019, vol. LXXIX, nº 263, septiembre-diciembre, págs. 757-784, ISSN: 0018-2141, e-ISSN: 1988-8368 https://doi.org/10.3989/hispania.2019.019 
19 de mayo, «ver si la acción» del ministro «disciplinando» a los regimientos alcalaínos incentivará las acciones de presión del «proletariado» y «cuánta provocación soportará el Ejército» ${ }^{49}$. Aparte de mal informado sobre los sucesos de Alcalá, Chilton sólo alcanzó a comprender parte de la encrucijada. El problema de Casares no era sólo si un sector del Ejército interpretaba lo de Alcalá como un castigo inmerecido, pues está claro que no podía tolerar una grave indisciplina si quería seguir siendo obedecido. La cuestión iba más allá: el Ejército había sido utilizado con frecuencia como pacificador de las calles en momentos de tensión extrema, sobre todo cuando los gobernadores y las policías se veían sobrepasados; y ahí estaban situaciones recientes para demostrarlo, incluida la misma Alcalá a principios de marzo de ese mismo año ${ }^{50}$. Pero era bien distinto que en los casos de violencia se hubieran visto involucrados oficiales desde el principio, como ocurrió en Alcalá en mayo o había pasado también en Logroño durante el mes de marzo; porque en estos casos, los socios obreros del Gobierno entendían que el Ejército era parte directa del problema, es decir, una extensión más de la amenaza fascista. En el contexto del mes de mayo, en el que la conspiración se extendía por los cuarteles y conseguía el respaldo de numerosos oficiales, el Gobierno no podía permitirse ser indulgente con la indisciplina sin verse acosado por sus socios parlamentarios. Ahora bien, como apuntaba el embajador, el caso de Alcalá también ponía sobre la mesa el doble riesgo que suponía castigar a los militares insubordinados por mor de evitar las amenazas de una huelga general con derivaciones violentas: que los sectores más radicalizados de las izquierdas interpretaran que el orden público estaba, de facto, en sus manos, mientras que los partidarios de derribar violentamente al Gobierno encontraban elementos con los que profundizar en la propaganda que inundaba los cuarteles asegurando que los preparativos de una revolución sobrepasaban a un ejecutivo impotente.

En definitiva, el conocimiento detallado de los casos de violencia en los que se vieron involucrados oficiales, como el de Alcalá, pueden contribuir a precisar mejor los términos en los que se desarrolló la relación entre el Ejército y el Gobierno en los meses de la primavera de 1936, yendo más allá de la perspectiva, necesaria pero insuficiente, sobre quiénes, cómo y cuándo prepararon el

${ }^{49}$ La traducción es nuestra, Informe del embajador británico en España, 19-5-1936, NA/ Foreign Office, 371/20.521, 249-250.

${ }^{50}$ Los ejemplos de resolución de problemas graves de orden público con la participación del Ejército se sucedieron desde el 17 de febrero en adelante: por ejemplo, en Zaragoza nada más empezar el recuento electoral (Diario de Almería (Almería), 18-2-1936. El Heraldo, Política (Madrid) y Diario de Valencia (Valencia), 19-2-1936). También se recurrió al ejército en Alcalá de Henares o en Cádiz a principios de marzo, tras la gravedad de la violencia incendiaria. ÁLVAREZ TARDÍO, 7 (Toledo, 2018): 327 y CARO CANCELA, 17 (2005): 67, respectivamente. Y no menos decisiva fue la intervención de las tropas en Badajoz, en plena ofensiva de ocupación de tierras a finales de marzo, ALÍA MIRANDA, 2011: 61. 
golpe militar. Si como se ha apuntado, la «presencia de los militares en las calles durante la primavera de 1936 ocasión[ó] inevitables tensiones con el elemento civil $\rangle^{51}$, merece la pena saber mejor por qué se desencadenaron esas tensiones y qué consecuencias tuvieron en medio de un clima de creciente divorcio entre una parte del Ejército y el Gobierno.

\section{Bibliografía}

Aguilar Olivencia, Mariano, El ejército español durante la Segunda República, Madrid, Econorte, 1986.

Alcalá-Zamora, Niceto, Asalto a la República. Enero-Abril de 1936, Madrid, Esfera de los Libros, 2011.

Alía Miranda, Francisco, Julio de 1936. Conspiración y alzamiento contra la Segunda República, Barcelona, Crítica, 2011.

Alonso Baquer, Miguel, Franco y sus generales, Madrid, Taurus, 2005.

Alpert, Michael, La reforma militar de Azaña (1931-1933), Madrid, Siglo XXI, 1982.

Alpert, Michael, El ejército popular de la República, 1936-1939, Barcelona, Crítica, 2007.

Álvarez Tardío, Manuel, «The Impact of Political Violence during the Spanish General Election of 1936», Journal of Contemporary History, 48/3 (Cambridge, 2013): 463-485.

Álvarez Tardío, Manuel, «Matar a Chocolate. Las autoridades y la violencia en la política local de la Segunda República española», Vínculos de Historia, 7 (Toledo, 2018): 311-330.

Álvarez Tardío, Manuel, José María Gil-Robles. Leader of the Catholic Right during the Spanish Second Republic, Brighton, Sussex Academic Press, 2018.

Álvarez Tardío, Manuel y Villa García, Roberto, El precio de la exclusión. La política durante la Segunda República, Madrid, Encuentro, 2010.

Álvarez Tardío, Manuel y Villa García, Roberto, «El impacto de la violencia anticlerical en la primavera de 1936 y la respuesta de las autoridades», Hispania Sacra, 132 (Madrid, 2013): 683-764.

Álvarez Tardío, Manuel y Villa García, Roberto, 1936. Fraude y violencia en las elecciones del Frente Popular, Madrid, Espasa, 2017.

Aróstegui Sánchez, Julio, Por qué el 18 de julio... y después, Barcelona, Flor del Viento, 2006.

Bahamonde, Ángel, «Partes de guerra antes de la guerra», Mélanges de la Casa de Velázquez, 41/1 (Madrid, 2011): 61-76.

Ballbé, Manuel, Orden público y militarismo en la España constitucional (1812-1983), Madrid, Alianza Editorial, 1983.

Bertrand Güell, Felipe, Preparación y desarrollo del Alzamiento nacional, Valladolid, Librería Santarén, 1939.

${ }^{51}$ BAHAMONDE, 41/1 (Madrid, 2011): 71.

Hispania, 2019, vol. LXXIX, nº 263, septiembre-diciembre, págs. 757-784, ISSN: 0018-2141, e-ISSN: 1988-8368

https://doi.org/10.3989/hispania.2019.019 
Blanco Escolá, Carlos, General Mola. El ególatra que provocó la guerra civil, Madrid, La Esfera de los Libros, 2002.

Blázquez Miguel, Juan, España turbulenta. Alteraciones, violencia y sangre durante la II República, Madrid, 2009.

Busquets, Julio, «La Unión Militar Española, 1933-1936», en La Guerra Civil, Historia 16, III, (Madrid, 1986): 86-99.

Cardona, Gabriel, El poder militar en la España contemporánea hasta la guerra civil, Madrid, Siglo XXI, 1983.

Cardona, Gabriel, Historia militar de una guerra civil. Estrategias y tácticas de la guerra de España, Barcelona, Flor del Viento, 2006.

Cardona, Gabriel, «El golpe de los generales», en Manuel Ballarín y José Luis Ledesma (eds.), La República del Frente Popular, Zaragoza, Fundación Rey del Corral, 2010: 149-163.

Caro Cancela, Diego, «Elecciones, conflictividad social y violencia política en la Andalucía del Frente Popular», Trocadero, 17 (2005): 57-75.

Cibrián, Ramiro, «Violencia política y crisis democrática: España en 1936», Revista de Estudios Políticos, 6 (Madrid, 1978): 81-115.

Cruz, Rafael, En el nombre del pueblo. República, rebelión y guerra en la España de 1936, Madrid, Alianza, 2006.

Fandiño Pérez, Roberto G., «Logroño 1936: la quema de conventos, mitos y realidades de un suceso anticlerical», Hispania Nova, 2 (Madrid, 2001).

Fernández-Coppel, Jorge, Queipo de Llano. Memorias de la Guerra Civil, Madrid, La Esfera de los Libros, 2008.

Franco Salgado-Araujo, Francisco, Mis conversaciones privadas con Franco, Barcelona, Planeta, 1976.

García Álvarez-Coque, Arturo, Los militares de Estado Mayor en la guerra civil española (1936-1939), tesis doctoral, Universidad Complutense de Madrid, 2017.

García Venero, Maximiliano, El General Fanjul. Madrid en el Alzamiento nacional, Madrid, Ediciones Cid, 1967.

Gil Andrés, Carlos, Echarse a la calle. Amotinados, huelguistas y revolucionarios (La Rioja, 1890-1936), Zaragoza, Prensas Universitarias de Zaragoza, 2000.

Gil-Robles, José María, No fue posible la paz, Barcelona, Planeta, 2006.

Goded Alonso, Manuel, Un «faccioso» cien por cien, Zaragoza, Talleres Editorial Heraldo, 1938.

González Calleja, Eduardo, Cifras cruentas. Las víctimas mortales de la violencia sociopolítica en la Segunda República española, Granada, Comares, 2015.

González Gullón, José Luis, El clero en la Segunda República. Madrid, 1931-1936, Burgos, Monte Carmelo, 2011.

Hidalgo, Diego, ¿Por qué fui lanzado del Ministerio de la Guerra?: diez meses de actuación ministerial, Madrid, Dracena, 2015.

Juliá, Santos, Vida y tiempo de Manuel Azaña (1880-1940), Madrid, Taurus, 2008.

Ledesma, José Luis, «La primavera trágica de 1936 y la pendiente hacia la guerra civil», en Francisco Sánchez Pérez (coord.), Los mitos del 18 de julio. Barcelona, Crítica, 2013: 313-339.

Lizarza, Antonio de, Memorias de la conspiración (1931-1936), Madrid, Dyrsa, 1986. Lledó, Pilar, Alcalá durante la II República, Alcalá de Henares, ACHAA, 1997. 
Macarro, José Manuel, Socialismo, República y Revolución en Andalucía (1931-1936), Sevilla, Universidad, 2000.

Maíz, Bernardo Félix, Alzamiento en España. De un diario de la conspiración, Pamplona, Gómez, 1952.

Martínez Barrio, Diego, Memorias, Barcelona, Planeta, 1983.

Martínez Roda, Federico, Varela: el general antifascista de Franco, Madrid, La Esfera de los Libros, 2012.

Muñiz, Alfredo, Días de horca y cuchillo. Diario 16 de febrero-15 de julio 1936, Sevilla, Espuela de Plata, 2009.

Payne, Stanley G., Los militares y la política en la España contemporánea, Madrid, Sarpe, 1986.

Payne, Stanley G., La primera democracia española. La II República, 1931-1936, Madrid, Paidós, 2005.

Payne, Stanley G., El camino al 18 de julio, Madrid, Espasa, 2016.

Puell de la Villa, Fernando, «La trama militar de la conspiración», en Francisco Sánchez Pérez (coord..), Los mitos del 18 de julio, Barcelona, Crítica, 2013: 55-78.

Ranzato, Gabrielle, El gran miedo de 1936, Madrid, Esfera de los Libros, 2011.

Rey, Fernando del, Paisanos en lucha. Exclusión política y violencia en la Segunda República española, Madrid, Biblioteca Nueva, 2008.

Rey, Fernando del, «Los papeles de un conspirador. Documentos para la historia de las tramas golpistas de 1936», Dimensioni e Problemi della Ricerca Storica, 2 (Roma, 2018): 129-159.

Rivas, Fernando, El Frente Popular. Antecedentes de un alzamiento, Madrid, Editorial San Martín, 1976.

Rivas García, Ramiro, ... y Franco salió de Tenerife. Franco en Canarias, Barcelona, Laertes Editorial, 2018.

Rodríguez Jiménez, José Luis, Franco, historia de un conspirador, Madrid, Oberon, 2005.

Sacanell, Enrique, El General Sanjurjo, héroe y víctima. El militar que pudo evitar la dictadura franquista, Madrid, La Esfera de los Libros, 2004.

Sacanell, Enrique, 1936. La conspiración, Madrid, Síntesis, 2008.

Sainz Rodríguez, Pedro, Testimonio y recuerdos, Barcelona, Planeta, 1978.

Salas Larrazábal, Jesús, Historia del ejército popular de la República. Vol I. De los comienzos de la guerra al fracaso del ataque sobre Madrid (noviembre de 1936), Madrid, Esfera de los Libros, 2006.

Togores Sánchez, Luis Eugenio, Yagüe, el general falangista de Franco, Madrid, La Esfera de los Libros, 2010.

Tusell, Javier, Franco en la Guerra Civil. Una biografía política, Barcelona, Tusquets, 1993.

Vadillo Muñoz, Julián, El movimiento obrero en Alcalá de Henares, (1868-1939), tesis doctoral, Universidad Complutense de Madrid, 2013.

Viñas, Ángel, La Alemania nazi y el 18 de julio, Madrid, Alianza Editorial, 1978.

Recibido: 06/11/2018

Aceptado: 07/05/2019

Hispania, 2019, vol. LXXIX, nº 263, septiembre-diciembre, págs. 757-784, ISSN: 0018-2141, e-ISSN: 1988-8368

https://doi.org/10.3989/hispania.2019.019 